\title{
Signature of ice streaming in Bjørnøyrenna, Polar North Atlantic, through the Pleistocene and implications for ice-stream dynamics
}

\author{
Karin ANDREASSEN, Monica WINSBORROW \\ Department of Geology, University of Tromsø, NO-9037 Tromsø, Norway \\ E-mail: karin.andreassen@uit.no
}

\begin{abstract}
The geomorphology of palaeo-ice-stream beds and the internal structure of underlying tills can provide important information about the subglacial conditions during periods of fast flow and quiescence. This paper presents observations from three-dimensional seismic data, revealing the geomorphology of buried beds of the Bjørnøyrenna (Bear Island Trough) ice stream, the main drainage outlet of the former Barents Sea ice sheet. Repeated changes in ice dynamics are inferred from the observed successions of geomorphic features. Megablocks, aligned in long chains parallel to inferred ice-stream flowlines, and forming dipping plates that are thrust one on top of another, are taken as evidence for conditions of compressive ice flow. Mega-scale glacial lineations (MSGL) and pull-apart of underlying sediment blocks suggest extensional flow. The observed pattern of megablocks and rafts overprinted by MSGL indicates a change in ice dynamics from a compressional to an extensional flow regime. Till stiffening, due to subglacial freezing, is the favoured mechanism for creating switches in sub-ice-stream conditions. The observed pattern of geomorphic features indicates that periods of slowdown or quiescence were commonly followed by reactivation and fast flow during several glaciations, suggesting that this may be a common behaviour of marine ice streams.
\end{abstract}

\section{INTRODUCTION}

Rapid changes in high-latitude ice masses (Rignot and Jacobs, 2002; De Angelis and Skvarca, 2003; Fricker and others, 2007) have raised concerns about the impact of predicted future global warming on the stability of these ice sheets and associated sea-level change (Alley and Bindschadler, 2001). Of particular concern is the marine-based West Antarctic ice sheet (WAIS), as much of its bed rests below sea level and small changes in its grounding line position could have large consequences for the ice sheet's overall stability (Bennett, 2003; Bindschadler, 2006). Icesheet discharge is dominated by ice streams, corridors where ice is moving much faster than the surrounding parts of the ice sheet (Bennett, 2003). The past decade of satellite and airborne measurements from contemporary ice sheets (Fahnestock and Bamber, 2001; Fricker and others, 2007) has revolutionized our understanding of ice-stream dynamics, but is limited to a fraction of the ice-stream operation time. Beds of palaeo-ice streams may reveal changes in icestream operation over longer timescales, and provide a more accessible source of information on the spatial variability in sub-ice-stream sedimentary processes (Ó Cofaigh and others, 2002; Dowdeswell and others, 2006; Mosola and Anderson, 2006). They may also reveal information about subglacial conditions and processes that are associated with ice-stream instability and shutdown (Christoffersen and Tulaczyk 2003; Clark and others, 2003). This study focuses on beds of the Bjørnøyrenna (Bear Island Trough) ice stream, which during glacial maxima was the main drainage outlet of the former Barents Sea ice sheet (BSIS; Fig. 1a and b).

The BSIS, located at the northern flank of the former Eurasian ice sheets, offers a good geological analogue to the contemporary WAIS. Similarities between the two ice sheets include a bed largely below sea level resting on sedimentary bedrock, a high-latitude location, and similar sizes during the Last Glacial Maximum (LGM), when both ice sheets were located at or near the shelf break (Fig. 1b and c). The
WAIS grounding line has in some areas retreated up to $1000 \mathrm{~km}$ since the LGM, whereas the BSIS went through a stepwise retreat, with the Barents Sea shelf largely deglaciated by $12 \mathrm{ka}$ (Landvik and others, 1998). Several archipelagos in the north and east of the Barents Sea are still partly glaciated.

We first present a short review of previous work on palaeo-ice-stream flow in Bjørnøyrenna (Fig. 1a). We then present new observations of buried geomorphic features and assemblages of landforms on and below beds of palaeo-ice streams. Finally we discuss the implications for ice-stream dynamics, shutdown and reactivation. The observations shed new light on the significance of subglacial landforms such as glacitectonic sediment blocks and rafts, and provide new insights into the future behaviour of contemporary ice streams.

\section{STUDY AREA AND GEOLOGICAL SETTING}

The Barents Sea covers one of the widest continental shelves in the world (Fig. 1a). It is bounded to the north and west by Tertiary rift and shear margins (Faleide and others, 1993), to the east by Novaya Zemlya and to the south by the Norwegian and Russian coasts. The sea-floor bathymetry is characterized by relatively shallow banks of 100-200 m, separated by troughs opening towards the Norwegian Sea and Arctic Ocean (Fig. 1a). Water depths within the troughs range typically from 300 to $500 \mathrm{~m}$. The most prominent trough is Bjørnøyrenna. Large trough mouth fans (TMF; Vorren and Laberg, 1997) at the western and northern Barents Sea margins (Fig. 1a) appear as seawards-convex bulges in the bathymetry at the mouths of the troughs that extend to the shelf edge (Fig. 1a). The study area has a three-dimensional (3-D) seismic dataset covering $2000 \mathrm{~km}^{2}$ at the southern flank of outer Bjørnøyrenna (Fig. 2; black-edged rectangle).

The southwestern Barents Sea margin has experienced subsidence since the Early Cretaceous, providing 

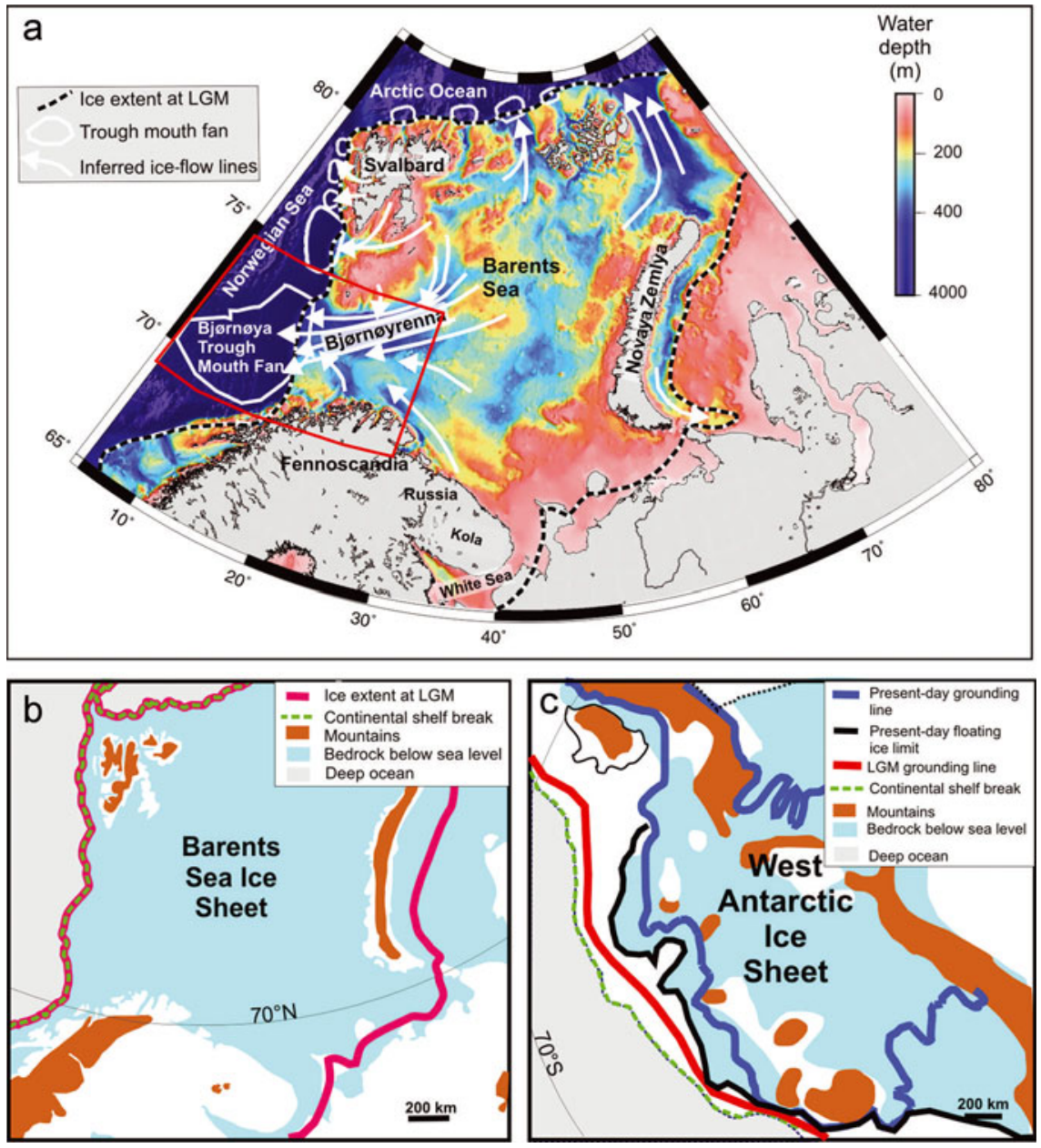

Fig. 1. (a) Shaded relief bathymetry of the Barents Sea. The red-edged box indicates location of Figure 2a. (b) Overview of the BSIS at the LGM ( 18-16 ka). (c) Overview of the contemporary WAIS. Modified from Oppenheimer (1998). LGM grounding line is from Anderson and Shipp (2001).

accommodation space for a thick Cretaceous to Cenozoic sedimentary succession (Gabrielsen and others, 1990). A cored Cenozoic section of the Bjørnøyrenna TMF (Fig. 3; 7216/11-1S) reveals deep-marine Early Palaeocene-Late Eocene sediments and shallow-marine Oligocene and Miocene successions (Ryseth and others, 2003). The PlioPleistocene glacial units (GI-GIII) form the huge, up to $3.5 \mathrm{~km}$ thick, Bjørnøya TMF (Fig. 2), which has a slope gradient of $0.2-0.8$

The three main sediment packages of the Bjørnøya TMF (GI, GII and GIII) are separated by regional seismic reflectors, R7, R5 and R1 (Fig. 2b), that can be correlated along the western Barents Sea-Svalbard continental margin (Faleide and others, 1996; Butt and others, 2000). The lowermost Gl unit is characterized by a progradational pattern of westerly-dipping clinoforms (Fig. 3), interpreted as shelf-margin, glacifluvial to glaciomarine sediments (Sættem and others, 1992b; Dahlgren and others, 2005). The slope facies of the Gll unit is characterized by a chaotic reflection pattern, inferred to represent large-scale mass-movement deposits related to slumps and slides (Kuvaas and Kristoffersen, 1996). The three largest of these are classified as megaslides, each containing over $500 \mathrm{~m}$ thick slide masses (Hjelstuen and others, 2007). The slope sediments of the uppermost (GIII) unit are characterized by units of stacked, mounded, lens-shaped bodies with a homogeneous internal structure, indicative of glacigenic debris flow deposits (Vorren and Laberg 1997; Hjelstuen and others, 2007). The palaeo-shelf sediments of Gll and GIII, characterized by a chaotic seismic reflection pattern, consist predominantly of sediments deposited by grounded glaciers (Faleide and others, 1996; Andreassen and others, 2004, 2007). Over $1000 \mathrm{~m}$ of bedrock has been eroded from the southeastern Barents Sea continental shelf during the Cenozoic (Nyland and others, 1992). A major part of this erosion is glacial and caused by fast-flowing ice streams draining through Bjørnøyrenna to the shelf break, delivering sediments to the Bjørnøya TMF and building up the GII and GIII sedimentary sequences (Andreassen and others, 2007). There is agreement in the published literature that the southwestern Barents Sea margin has been affected by grounded ice reaching the shelf edge several times during the last 1-1.5 Ma (Fig. 3, Environment column; Faleide and others, 1996; Andreassen and others, 2004, 2007; Dahlgren and others, 2005), although the chronology is somewhat uncertain.

\section{PREVIOUS WORK ON PALAEO-ICE-STREAM FLOW IN THE SOUTHWESTERN BARENTS SEA}

Recent publications of regional sea-floor bathymetry and 3-D seismic data have provided detailed information on 


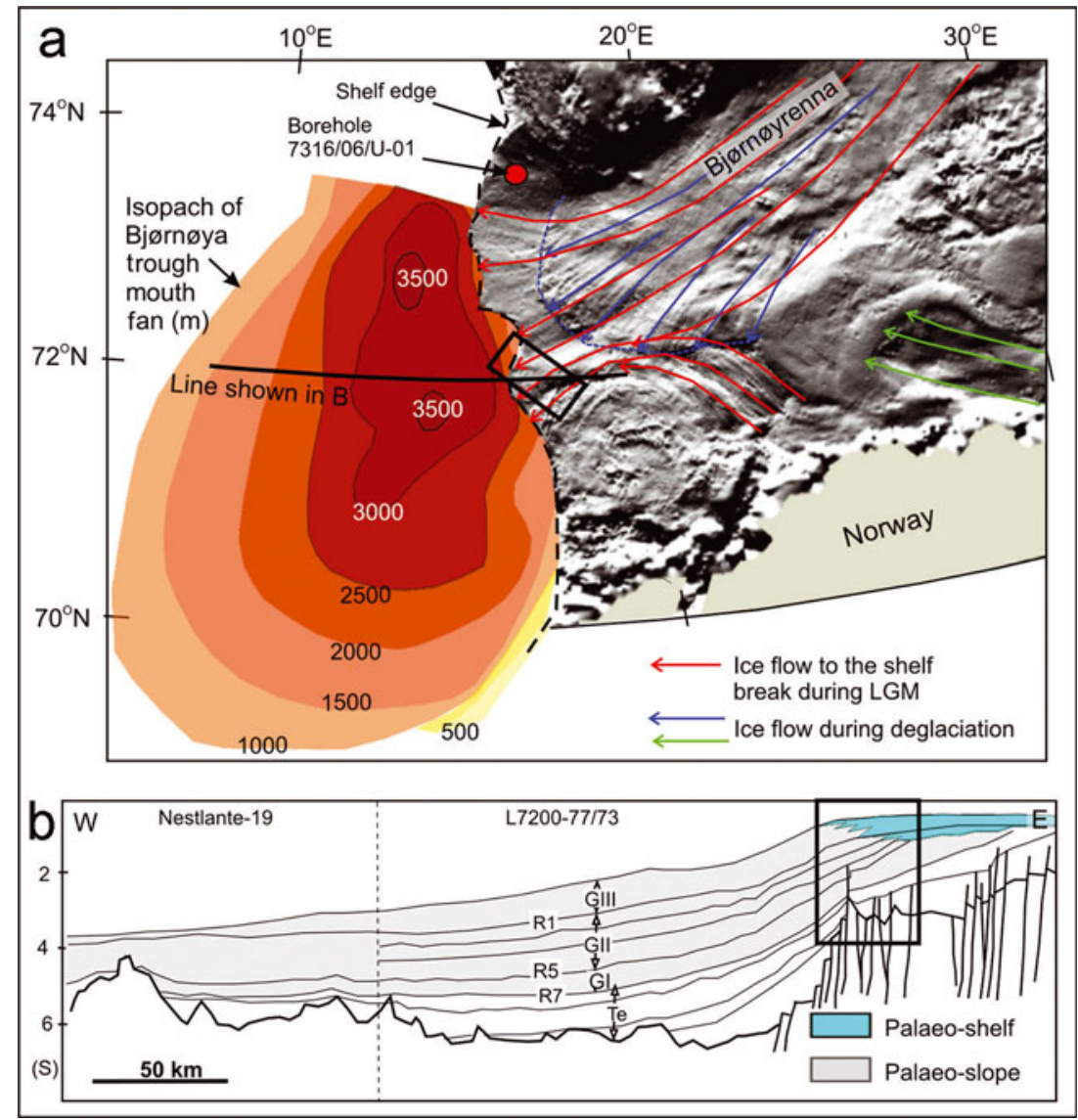

Fig. 2. (a) Illuminated perspective view of the southwestern Barents Sea and isopachs showing thickness of the Pli-Pleistocene GI-GII sediment units of the Bjørnøya TMF (in metres; modified from Fiedler and Faleide, 1996). The inferred ice flowlines are simplified from Andreassen and others (2008). Te: Pre-Pliocene Tertiary sediments. Location is shown in Figure 1a. (b) Geoseismic profile with location as indicated in (a). The black-edged boxes in (a) and (b) indicate location of the 3-D seismic dataset used in this study.

glacial geomorphic features and evidence for different glacial regimes during the Late Weichselian glaciation (Ottesen and others, 2005; Andreassen and others, 2007, 2008). The sea-floor morphology of the major cross-shelf troughs of the southwestern Barents Sea is characterized by mega-scale glacial lineations (MSGL), inferred to represent flowlines of former ice streams that operated during the Late Weichselian glaciation. These indicate a highly

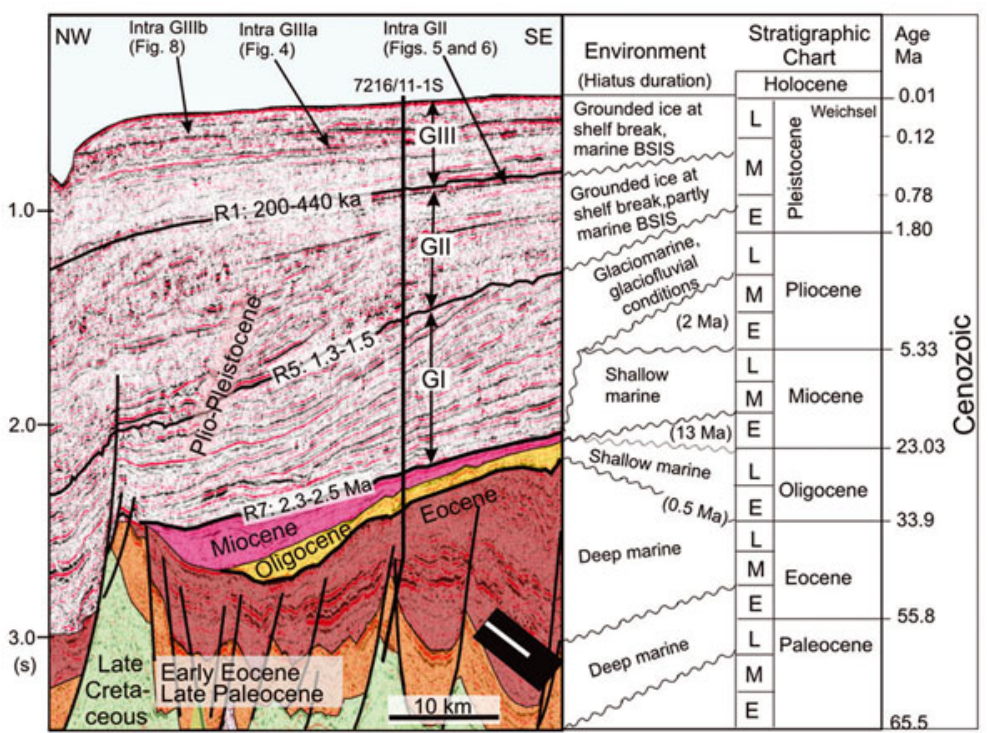

Fig. 3. Interpreted seismic profile from the $3-D$ dataset at the shelf break of the Bjørnøya TMF and stratigraphic chart. Pre-Pliocene stratigraphy and environment are from Ryseth and others (2003). Plio-Pleistocene age estimates, although uncertain, are from Faleide and others (1996) and Butt and others (2000). E: Early; M: Middle; L: Late. 


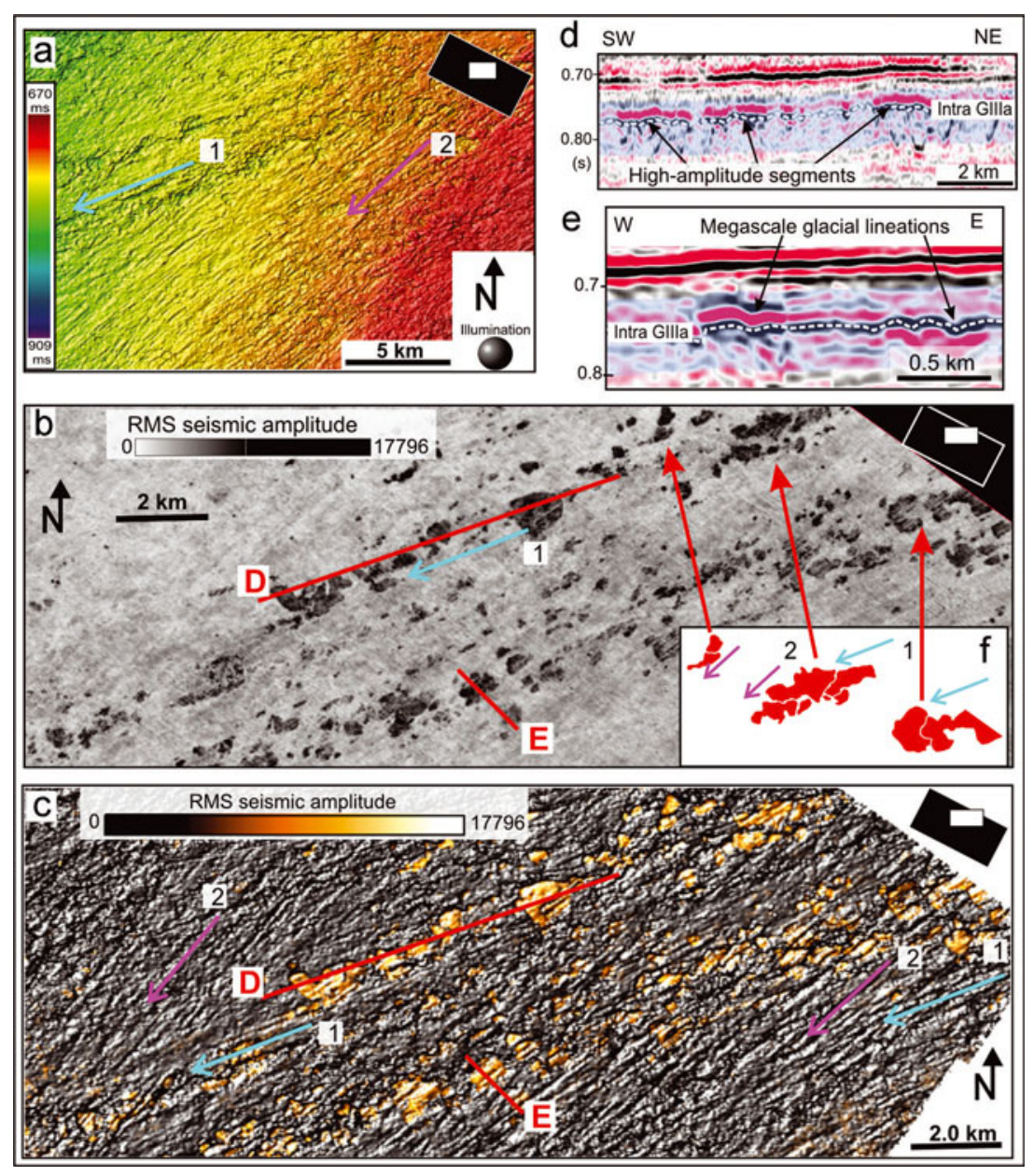

Fig 4. (a) Illuminated shaded relief image of seismic horizon Intra GIlla. Stratigraphic level is indicated in Figure 3. (b) Root mean square (RMS) of the seismic amplitude of the volume indicated by the shaded bands in (d) and (e). (c) The dark areas represent megablocks and rafts of different sediment type than the surrounding material. The blue arrow indicates orientation of chains of sediment blocks. (d, e) Seismic profiles showing high-amplitude reflection segments just below the Intra Gllla seismic horizon. (f) The red parts illustrate that many of the sediment blocks of (b) and (c) fit together like parts of a jigsaw puzzle. The blue and purple arrows indicate directions of pull-apart of sediment blocks in ( $\mathrm{f}$ ) and orientation of MSGL in (a-c). (a), (b), (c) and (f) are modified from Andreassen and others (2007).

dynamic system with several generations of ice streams operating in the troughs. Based on spatial coherency of flow patterns and association with other glacial geomorphic features, the MSGL have been grouped into distinct flow sets related to specific ice-flow events (Fig. 2a; Andreassen and others, 2008). The oldest flow event (Fig. 2a, red arrows) indicates that a major ice stream was draining through Bjørnøyrenna to the western Barents Sea shelf break, sourced by the Barents Sea and Fennoscandian ice sheets. This flow event represents the LGM, and its last phase has an age estimate of 18-16 ka BP (Vorren and others, 1990). The blue and green flowlines in Figure 2a relate to ice streams that operated during the deglaciation (Andreassen and others, 2008).

Ice streaming in Bjørnøyrenna during the pre-Late Weichselian has been inferred from MSGL on buried horizons within the GII and GIII shelf units (Figs 4a and $5 \mathrm{a})$ and long chains of sediment blocks and rafts in thick till units (Fig. 4b; Andreassen and others, 2004, 2007), based on interpretation of the 3-D seismic dataset from the southern flank of outer Bjørnøyrenna (Fig. 2a). Detailed observations from three of the buried, palaeo-ice-stream beds (Fig. 3; Intra GII, Intra GIIla and Intra GIIIb) are presented here.

\section{SEISMIC DATA AND METHODS}

Results from an industry-based 3-D seismic dataset covering an area of $2000 \mathrm{~km}^{2}$ at the southern flank of outer Bjørnøyrenna (Fig. 2a; black-edged rectangle) are presented here. The 3-D data have relatively low frequency (around $60 \mathrm{~Hz}$ ) and hence a vertical resolution of around $10 \mathrm{~m} \mathrm{(a}$ quarter of the seismic wavelet and assuming a velocity of $1600 \mathrm{~m} \mathrm{~s}^{-1}$ ). This is poor compared to the high-frequency two-dimensional (2-D) acoustic data with vertical resolution better than $2 \mathrm{~m}$ now typically used in studies of marine glacial sediments (Ó Cofaigh and others, 2008). However, the horizontal resolution of this 3-D seismic data is dramatically improved compared to that of 2-D data due to high spatial sampling rate $(12.5 \mathrm{~m})$ and $3-\mathrm{D}$ migration techniques, and is in theory around $12 \mathrm{~m}$.

Three-dimensional seismic data have been used by the hydrocarbon industry since the early 1990s, and during the last decade have been increasingly used in academic investigations of glacial sediments (Lyngren and others, 1997; Praeg, 1997; Praeg and Long, 1997; Rafaelsen and others, 2002; Andreassen and others, 2004, 2007; Long and others, 2004; Bulat, 2005; Ottesen and others, 2005; Dowdeswell and others, 2006; Graham and others, 2007). 


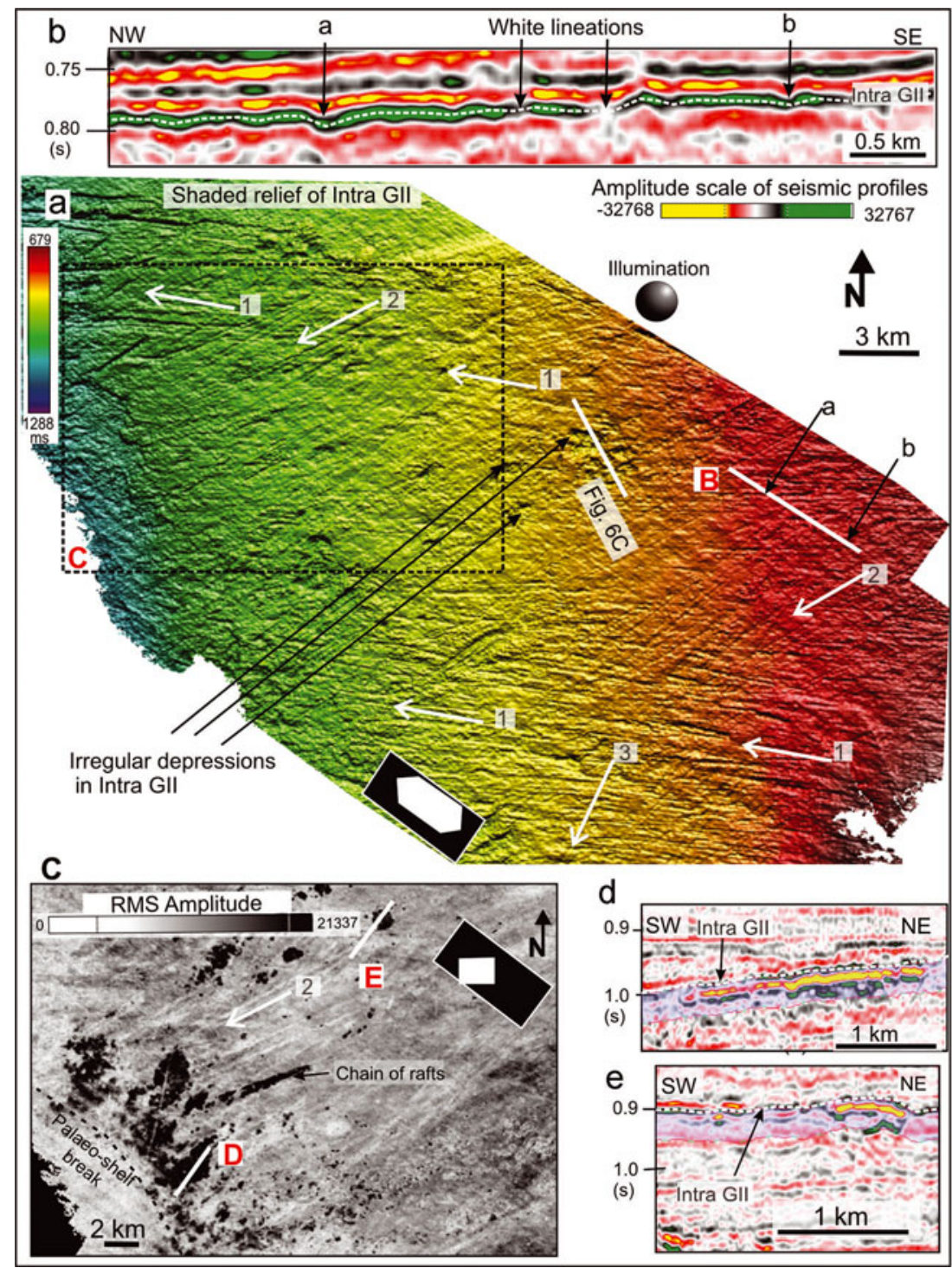

Fig. 5. (a) Shaded relief image of Intra GIl buried horizon showing MSGL with different orientations (arrows marked 1, 2 and 3). (b) Seismic section with location indicated in (a). (c) RMS of the seismic amplitude of the volume indicated by the shaded bands in (d) and (e). (d, e) Seismic profile showing high-amplitude reflection segments just below the Intra Gll seismic horizon.

In this study, 3-D seismic technology is used to investigate the detailed geomorphology and internal structure of palaeo-ice-stream beds and till units.

\section{GEOMORPHOLOGY OF BURIED GLACIAL HORIZONS}

\section{Observations of glacial lineations and depressions on a palaeo-ice-stream bed}

Andreassen and others (2007) reported that shaded relief and seismic amplitude images of the Intra Gll horizon show many MSGL. These can be grouped into three different orientations (Figs 5a and 6a, white arrows). The lineations have reliefs of up to $10 \mathrm{~m}$, are $50-360 \mathrm{~m}$ wide, and some are over $38 \mathrm{~km}$ long and have elongation ratios $>100: 1$. The first group of MSGL are east-southeast-west-northwestoriented furrows, which are well developed over the entire shaded relief image (Fig. 5a, orientation 1), but barely visible on the image of seismic amplitude (Fig. 6a, orientation 1). MSGL with orientations 2 and 3 are well developed on the seismic amplitude map, where they appear as white lines
(Fig. 6a), but can hardly be seen on the shaded relief image (Fig. 5a).

Here the different appearance of the three sets of lineations on the shaded relief and the seismic amplitude images can be understood by investigation of vertical seismic sections and provides information on the processes of MSGL formation. Large areas on the Intra Gll seismic amplitude image have either very high amplitude values (Fig. 6a, dark-grey to black areas) or very low amplitude values (Fig. 6a, light-grey to white areas). A vertical seismic section crossing a range of amplitudes (Fig. 6d) indicates that the high amplitude values (coloured green areas on the seismic profiles) are caused by positive interference between seismic reflections that converge towards the northeast on the profile. The dark areas on the Intra GII amplitude image are therefore areas where the Intra GII reflection is caused by positive interference of seismic reflections from two bedding planes, or a layer. White lineations (groups 2 and 3) are areas where this layer has been completely or partly removed (Fig. 7), confirming that these MSGL are erosional features. 


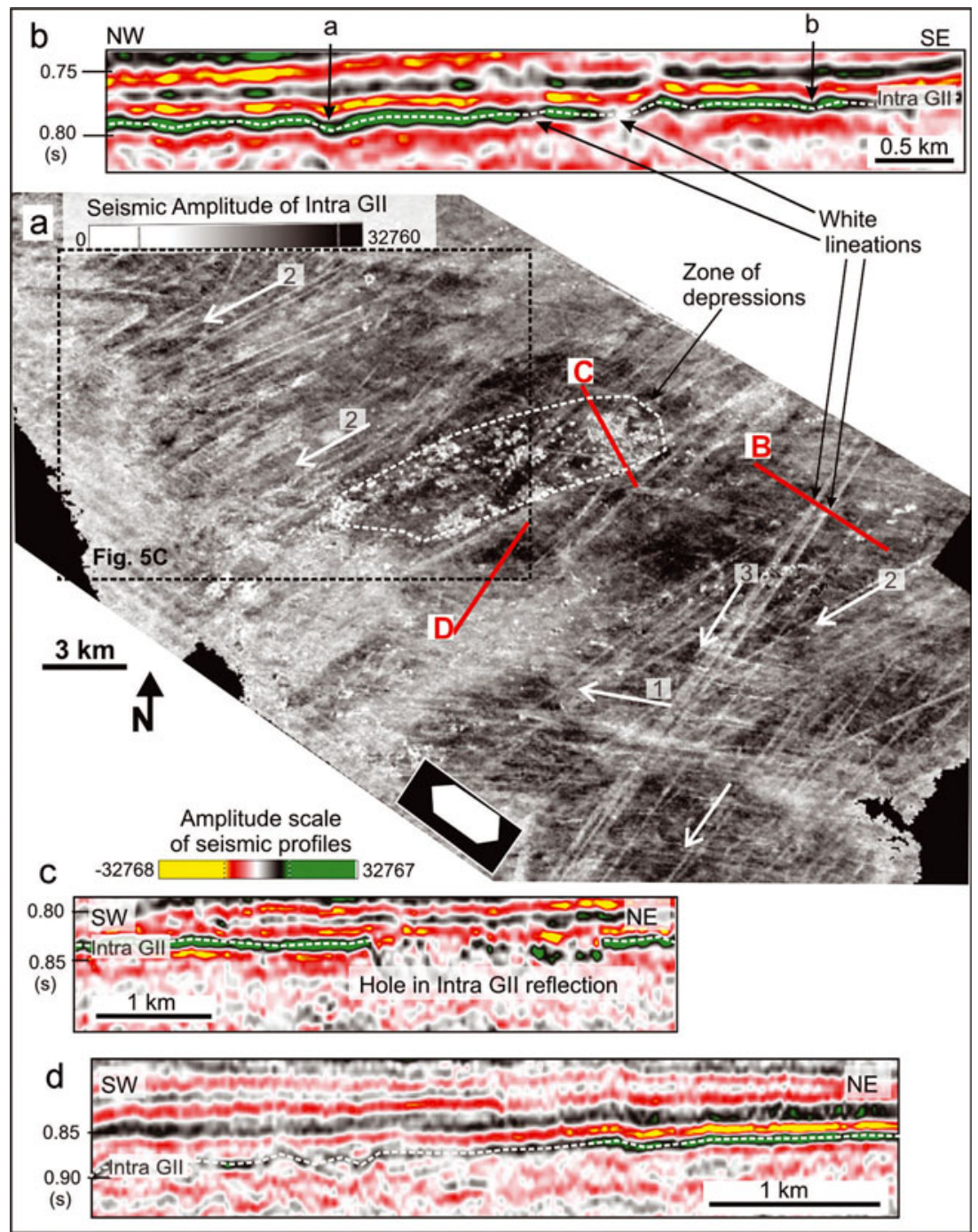

Fig. 6. (a) Reflection amplitude of seismic horizon Intra Gll showing MSGL with different orientations (arrows marked 1, 2 and 3 ). (b-d) Seismic sections with locations indicated in (a).

In addition to MSGL, irregular depressions are present on the Intra Gll shaded relief image (Fig. 5a). These depressions appear as irregular, white areas on the Intra Gll amplitude image (Fig. 6a). They are located in a $3-4 \mathrm{~km}$ wide and $12 \mathrm{~km}$ northeast-southwest-trending zone in the middle of the study area. The largest hole in the northeastern part of this zone (Fig. 6c) is $2.9 \mathrm{~km}$ wide, while those to the southwest are from $1 \mathrm{~km}$ to a few hundred metres wide. Inspection of vertical seismic sections (Fig. 6c) indicates that these depressions are areas where the Intra Gll reflection terminates abruptly. The layer that gives rise to this reflection must therefore have been removed, leaving holes in the strong reflection.

\section{SEDIMENT BLOCKS AND RAFTS IN SUB-ICE- STREAM BED TILL UNITS}

\section{Observations}

The internal structure of the sediments below the Intra GII horizon (i.e. below the palaeo-ice-stream bed) is revealed by the root-mean-square (RMS) amplitude map, calculated for a $50 \mathrm{~m}$ (assuming a velocity of $2000 \mathrm{~ms}^{-1}$ ) thick stratigraphic volume (Fig. $5 \mathrm{~d}$ and e; shaded bands). The RMS amplitude image (Fig. 5c) shows that high-amplitude reflection segments, on the vertical seismic sections at the level of and just below Intra GII, represent sediment bodies of a different sediment type (much higher product of density and velocity) compared to the surrounding sediments. The RMS image indicates that the largest sediment bodies consist of clusters, each a few hundred metres wide, rather than individual, large sediment blocks. With an areal extent $<1 \mathrm{~km}^{2}$, the individual sediment bodies are classified as rafts (Aber and others, 1989). A $10 \mathrm{~km}$ long and $1-2 \mathrm{~km}$ wide chain of closely spaced sediment rafts in the centre of the RMS image (Fig. 5c) has the same northeast-southwesttrending orientation as the MSGL of flow set 2 . The clusters of sediment rafts appear on vertical seismic sections as highamplitude reflection segments with an irregular upper and lower boundary (Fig. 5d and e), and the internal structure of single rafts cannot be resolved. We therefore include observations from the shallower Glllb level (Fig. 3), where the internal structure of sediment blocks is very clear (Fig. 8c).

The largest sediment bodies in the till just below the Intra Gillb palaeo-ice-stream bed are $>1 \mathrm{~km}^{2}$ and hence classified as medium-sized megablocks (Aber and others, 1989), while the smaller are $100-400 \mathrm{~m}$ wide sediment rafts. The 


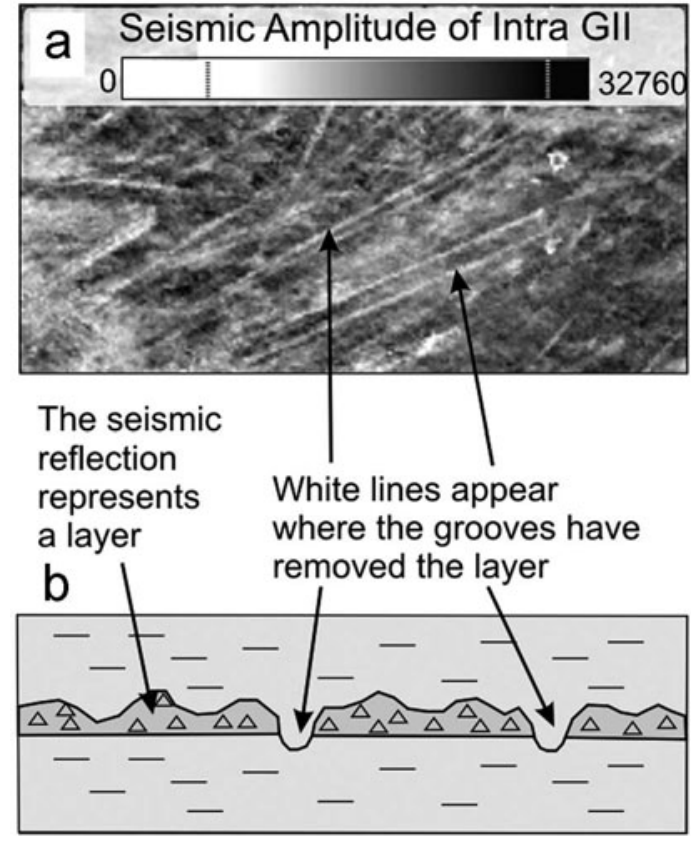

Fig. 7. (a) Reflection amplitude of seismic horizon Intra GIl (detail from Fig. 6a). White lines indicate MSGL. (b) Sketch illustrating interpretation of the appearance of MSGL as white lines on seismic amplitude images.

sediment blocks are well imaged by a map showing seismic amplitude of Intra Glllb (Fig. 8a). Some of the blocks are aligned along a northeast-southwest-trending chain (northeast in Fig. 8a), with the same orientation as MSGL flow set 1 on the top block surface (Fig. 8b; arrow marked 1). Vertical seismic sections parallel to the sediment chain clearly indicate that most of the megablocks are tilted upstream, often in an imbricated manner (Fig. 8c; sediment blocks in central and southwestern part of profile), while others have a more sub-horizontal orientation (Fig. 8c; sediment blocks in northeastern part of profile). The concentration of sediment blocks is highest in a $5 \mathrm{~km}$ wide zone trending parallel to and $4-10 \mathrm{~km}$ upstream of the palaeo-shelf edge (Fig. 8a).

\section{INTERPRETATIONS}

The MSGL on the buried GII and GIII horizons are interpreted as formed by fast ice flow (Andreassen and others, 2007). The MSGL on the Intra Gll horizon with orientations 2 and 3 are, from their northeast-southwesttrending orientation, most likely associated with ice draining through Bjørnøyrenna from the Barents Sea. The MSGL of orientation 1 indicate ice flow from the east-southeast, probably from the Norwegian mainland. The integration of the Intra Gll amplitude image (Fig. 6a) with vertical sections (Fig. 6b) indicates that the lineations on this horizon must be mainly erosional grooves rather than depositional ridges. The appearance of white lines on the amplitude image suggests that the grooves with orientations 2 and 3 have removed the layer that gives rise to the Intra Gll strong seismic reflection (Fig. 7), whereas the grooves with orientation 1 are not as deep.

The depressions in the Intra Gll horizon have the same northeast-southwest orientation as the Intra GII MSGL with orientation 2 (Fig. 6b). We suggest that the holes are areas where subglacial sediment blocks and rafts have been removed and deposited farther downstream. We have inspected downstream areas at slightly higher stratigraphic levels, but no sediment blocks have been detected. However, the holes are located just $10-20 \mathrm{~km}$ from the shelf break, where a well-developed slide scar appears at this stratigraphic level, and it seems likely that sediment bodies removed from the holes have been transported to the shelf break and mobilized down the slope.

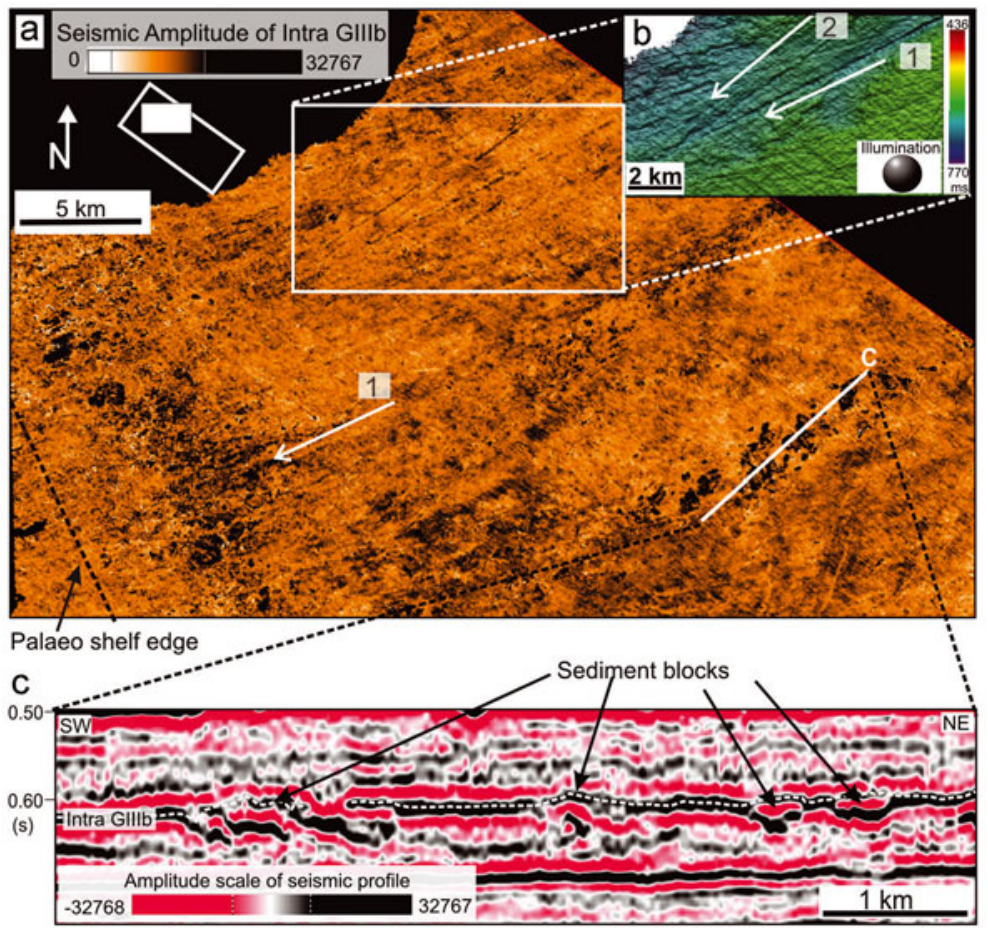

Fig. 8. (a) Seismic amplitude of Intra GIIlb reflection. (b) Shaded relief image of Intra Glllb. (c) Seismic profile with location as indicated in (a). 
The chains of sediment blocks and rafts at the stratigraphic levels Intra GII (Fig. 5c) and Intra GIIlb (Fig. 8a) are parallel to MSGL on the horizons at the top of the sediment bodies, in both cases inferred to have been deposited by the same glacial events that formed the MSGL. The observed holes on the Intra Gll glacial horizon are the first direct evidence that glacitectonic sediment blocks in the southwestern Barents Sea consist of till material because the holes are formed in till material.

\section{DISCUSSION: SUBGLACIAL DEFORMATION AND ICE-STREAM DYNAMICS}

It is generally held that the fast flow of ice streams and the switching between fast flow and quiescence is linked to subglacial processes and sediment deformation (Boulton and Hindmarsh, 1987; Fisher and Clarke, 2001), but the processes involved remain poorly understood and the depth of subglacial deformation remains uncertain (Clarke, 2005). Here we link the different geomorphic features that have been observed to different conditions of ice-stream flow, and discuss the implications of observed landform assemblages for ice-stream dynamics.

\section{Features of compressional ice flow}

The sediment blocks described above form dipping plates that are thrust one on top of the other (Fig. 8c), indicative of entrainment into the ice under conditions of compressive ice flow. The depth of dislocation is difficult to estimate from the seismic data, because many of the sediment blocks are too small to be properly resolved on vertical sections and are often stacked upon each other. However, the sub-horizontal sediment plates subcropping Intra GIIIb (Fig. 8c, northeastern part of profile) seem to be around $25 \mathrm{~m}$ thick. A geotechnical borehole from the northern flank of outer Bjørnøyrenna (Fig. 2a; 7316/06-U-01) revealed the existence of a 15-25 m thick block of consolidated Cretaceous bedrock, which was embedded in very stiff, Late Weichselian till (Sættem, 1994). These observations indicate that failure of sub-ice-stream till occurred at least to depths of $25 \mathrm{~m}$ in Bjørnøyrenna.

\section{Features of extensional ice flow}

Andreassen and others (2004, 2007) observed that many of the sediment blocks just below Glla fit together like parts of a jigsaw puzzle (Fig. $4 b$ and f). Based on the shape of the sediment bodies and how the different blocks must be moved to fit together, we propose two pull-apart directions (Fig. 4f, arrows 1 and 2), and suggest that tearing apart must have taken place under conditions of extensional ice flow. The two inferred pull-apart directions are the same as the orientations of MSGL of orientation 1 at the top block surface (Fig. 4c). From this we infer that both the tearing apart of sediment blocks and the formation of MSGL took place under an extensional flow regime of ice-stream activity. Figure 4c clearly reveals that the MSGL are furrows that have eroded into the sediment blocks and split several of them into different pieces. MSGL of the intra Gll horizon are also inferred to represent erosional furrows.

\section{Implications for ice-stream dynamics}

Our observations of buried palaeo-ice-stream bed geomorphology and the structure of underlying sediment blocks indicate a switching between compressional subglacial flow and extensional subglacial flow. Glacitectonic deformation of subglacial till suggests that the till must have been stiff. Industrial geotechnical boreholes and seabed cores from Bjørnøyrenna reveal that the typical till here is an overconsolidated, massive, muddy diamicton, consisting of silty, sandy clay with scattered gravel (Sættem and others, 1992a). Based on geotechnical studies, Sættem and others (1992a) suggested that these characteristics result from basal freezing, which is known to cause overconsolidation of subglacial sediments (Sættem and others, 1996), and can produce a rheological contrast between the frozen sediments at the ice base and underlying less consolidated sediments. This may focus sediment deformation at the transition between the overconsolidated and less-consolidated sediments (Andreassen and others, 2007). Alternatively, the till stiffness could result from dewatering. A switch in the sub-ice-stream drainage system from a distributed system of broad, shallow channels to a more efficient system of much larger lowdensity Röthlisberger channels, as suggested for the subglacial till of the Dubawnt Lake ice stream of the former Laurentide ice sheet (Stokes and others, 2008), could create such dewatering. However, meltwater channels are rarely observed in Bjørnøyrenna, nor are they common on the slope of the Bjørnøya TMF (Taylor and others, 2002). We therefore favour a mechanism of till stiffening due to subglacial freezing, creating the switch between extensional and compressional ice flow.

Freeze-on can occur without necessarily stopping an ice stream. In the WAIS there is evidence for several metres of freeze-on under the active Whillans and Bindschadler Ice Streams, and also that parts of the 10-14 m of debris-rich ice that is frozen to the bed of the stopped Kamb Ice Stream must have occurred before the ice stream shut down (Kamb, 2001). However, once basal freeze-on is initiated, removal of water from the subglacial system decreases basal lubrication and may cause a complete shutdown in as short a time as 100 years (Bougamont and others, 2003).

The observed sequences of sediment blocks and rafts overlain by MSGL are repeated at many different stratigraphic levels of the study area. This pattern indicates that periods of slowdown or quiescence were commonly followed by reactivation and fast ice-stream flow, suggesting that this may be a common behaviour of marine ice streams. This leaves open the possibility that the stopped Kamb Ice Stream may experience a new period of fast flow. The observations at the Intra Gll horizon (Figs 6 and 7) suggest that slowdown and fast flow was followed by a second phase of sub-ice-stream glacitectonic erosion, leaving a long chain of kilometre-wide holes on the palaeo-ice-stream bed (Fig. 6a). Such oscillations in ice-stream flow are consistent with thermodynamic models (Bougamont and others, 2003) and suggest that the life cycle of marine ice streams includes alternating periods of activity and quiescence.

\section{CONCLUSIONS}

In this paper, the geomorphology and internal structure of palaeo-ice-stream beds in Bjørnøyrenna have been investigated from 3-D seismic data. Detailed observations from three different stratigraphic levels of the buried sub-icestream sediments revealed sequences of geomorphic features diagnostic of cycles of ice-stream slowdown or quiescence, followed by reactivation and fast flow.

The orientations of MSGL on palaeo-ice-stream beds and underlying chains of megablocks and rafts indicate that they 
were formed by the same ice-streaming events. Based on interpretation of 3-D seismic attributes and vertical seismic sections revealing the internal structure of buried till units, we suggest that the megablocks and rafts are glacitectonically entrained into the ice under conditions of compressive ice flow. MSGL on the palaeo-ice-stream beds and the pull-apart of underlying sediment blocks must have taken place under conditions of extensional ice flow. We favour a mechanism of till stiffening due to subglacial freezing creating the switch from extensional to compressional ice-stream flow. The sediment blocks and the depressions they created are associated with compressional ice flow and inferred to be signatures of sub-ice-stream thermal sticky spots.

The observed pattern of geomorphic features indicates that periods of slowdown or quiescence were commonly followed by reactivation and fast flow, suggesting that this may be a common behaviour of marine ice streams.

\section{ACKNOWLEDGEMENTS}

We thank the Norwegian Petroleum Directorate for funding the position of M. Winsborrow, Schlumberger for seismic interpretation software, StatoilHydro for providing data, B.I. Evje and S. Buenz for keeping the software running and C. Ødegaard for making an earlier version of one of the figures. This is a contribution to the PetroMax Programs 'Ice ages: subsidence, uplift and tilting of traps - the influence on petroleum systems (GLACIPET)' and 'Depositional models for Cenozoic sandy systems (DEMOCEN)' funded by the Research Council of Norway (NFR) and StatoilHydro. The manuscript benefited considerably from the constructive comments of C. Ó Cofaigh, an anonymous reviewer and the scientific editor, C. Clark.

\section{REFERENCES}

Aber, J.S., D.G. Croot and M.M. Fenton. 1989. Glaciotectonic landforms and structures. Dordrecht, etc., Kluwer Academic Publishers.

Alley, R.B. and R.A. Bindschadler. 2001. The West Antarctic ice sheet and sea-level change. In Alley, R.B. and R.A. Bindschadler, eds. The West Antarctic ice sheet: behavior and environment. Washington, DC, American Geophysical Union, 1-11. (Antarctic Research Series 77.)

Anderson, J.B. and S.S. Shipp. 2001. Evolution of the West Antarctic ice sheet. In Alley, R.B. and R.A. Bindschadler, eds. The West Antarctic ice sheet: behavior and environment. Washington, DC, American Geophysical Union, 45-57. (Antarctic Research Series 77.)

Andreassen, K., L.C. Nilssen, B. Rafaelsen and L. Kuilman. 2004. Three-dimensional seismic data from the Barents Sea margin reveal evidence of past ice streams and their dynamics. Geology, 32(8), 729-732.

Andreassen, K., C. Ødegaard and B. Rafaelsen. 2007. Imprints of former ice streams, imaged and interpreted using industry threedimensional seismic data from the southwestern Barents Sea. In Davies, R.J., H.W. Posamentier, L.J. Wood and L.J. Cartwright, eds. Seismic geomorphology: applications to hydrocarbon exploration and production. London, Geological Society, 151-169.

Andreassen, K., J.S. Laberg and T.O. Vorren. 2008. Seafloor geomorphology of the SW Barents Sea and its glaci-dynamic implications. Geomorphology, 97(1-2), 157-177.

Bennett, M.R. 2003. Ice streams as the arteries of an ice sheet: their mechanics, stability and significance. Earth-Sci. Rev., 61(3-4), 309-339.
Bindschadler, R.A. 2006. Hitting the ice sheets where it hurts. Science, 311(5768), 1720-1721.

Bougamont, M., S. Tulaczyk and I. Joughin. 2003. Response of subglacial sediments to basal freeze-on: 2. Application in numerical modeling of the recent stoppage of Ice Stream C, West Antarctica. J. Geophys. Res., 108(B4), 2223. (10.1019/ 2002JB001936.)

Boulton, G.S. and R.C.A. Hindmarsh. 1987. Sediment deformation beneath glaciers: rheology and geological consequences. J. Geophys. Res., 92(B9), 9059-9082.

Bulat, J. 2005. Some considerations on the interpretation of seabed images based on commercial 3D seismic in the Faroe-Shetland Channel. Basin Res.,17(1), 21-42.

Butt, F.A., A. Elverhøi, A. Solheim and C.-F. Forsberg. 2000. Deciphering Late Cenozoic development of the western Svalbard Margin from ODP Site 986 results. Mar. Geol., 169(3-4), 373-390.

Christoffersen, P. and S. Tulaczyk. 2003. Signature of palaeo-ice stream stagnation: till consolidation induced by basal freeze-on. Boreas, 32(1), 114-129.

Clark, C.D., S.M. Tulaczyk, C.R. Stokes and M. Canals. 2003. A groove-ploughing theory for the production of mega-scale glacial lineations, and implications for ice-stream mechanics. J. Glaciol., 49(165), 240-256.

Clarke, G.K.C. 2005. Subglacial processes. Annu. Rev. Earth Planet. Sci., 33, 247-276.

Dahlgren, K.I.T., T.O. Vorren, M.S. Stoker, T. Nielsen, A. Nygård and H. Serjup. 2005. Late Cenozoic prograding wedges on the NW European continental margin: their formation and relationship to tectonics and climate. Mar. Petrol. Geol., 22(9-10), 1089-1110.

De Angelis, H. and P. Skvarca. 2003. Glacier surge after ice shelf collapse. Science, 299(5612), 1560-1562.

Dowdeswell, J.A., D. Ottesen and L. Rise. 2006. Flow switching and large-scale deposition by ice streams draining former ice sheets. Geology, 34(4), 313-316.

Fahnestock, M. and J. Bamber. 2001. Morphology and surface characteristics of the West Antarctic ice sheet. In Alley, R.B. and R.A. Bindschadler, eds. The West Antarctic ice sheet: behavior and environment. Washington, DC, American Geophysical Union, 13-27. (Antarctic Research Series 77.)

Faleide, J.I., E. Vågnes and S.T. Gudlaugsson. 1993. Late MesozoicCenozoic evolution of the southwestern Barents Sea in a regional rift-shear tectonic setting. Mar. Petrol. Geol., 10(3), 186-214.

Faleide, J.I., A. Solheim, A. Fiedler, B.O. Hjelstuen, E.S. Andersen and K. Vanneste. 1996. Late Cenozoic evolution of the western Barents Sea-Svalbard continental margin. Global Planet. Change, 12(1-4), 53-74.

Fiedler, A. and J.I. Faleide. 1996. Cenozoic sedimentation along the southwestern Barents Sea margin in relation to uplift and erosion of the shelf. Global Planet. Change, 12(1-4), 75-93.

Fisher, U.H. and G.K.C. Clarke. 2001. Review of subglacial hydro-mechanical coupling: Trapridge Glacier, Yukon Territory, Canada. Quat. Int., 86(1), 29-43.

Fricker, H.A., T. Scambos, R. Bindschadler and L. Padman. 2007. An active subglacial water system in West Antarctica mapped from space. Science, 315(5818), 1544-1548.

Gabrielsen, V., R.B. Færseth, L.N. Jensen, J.E. Kalheim and F. Riis. 1990. Structural elements of the Norwegian continental shelf. Part I: The Barents Sea Region. Nor. Petrol. Dir. Bull. 6.

Graham, A.G.C., L. Lonergan and M.S. Stoker. 2007. Evidence for Late Pleistocene ice stream activity in the Witch Ground Basin, central North Sea, from 3D seismic reflection data. Quat. Sci. Rev., 6(5-6), 627-643.

Hjelstuen, B.O., O. Eldholm and J.I. Faleide. 2007. Recurrent Pleistocene mega-failures on the SW Barents Sea margin. Earth Planet. Sci. Lett., 258(3-4), 605-618.

Kamb, B. 2001. Basal zone of the West Antarctic ice streams and its role in lubrication of their rapid motion. In Alley, R.B. and 
R.A. Bindschadler, eds. The West Antarctic ice sheet: behavior and environment. Washington, DC, American Geophysical Union, 157-199. (Antarctic Research Series 77.)

Kuvaas, B. and Y. Kristoffersen. 1996. mass movements in glaciomarine sediments on the Barents continental slope. Global Planet. Change, 12(1-4), 287-307.

Landvik, J.Y. and 8 others. 1998. The Last Glacial Maximum of Svalbard and the Barents Sea area: ice sheet extent and configuration. Quat. Sci. Rev., 17(1-3), 43-75.

Long, D., J. Bulat and M.S. Stoker. 2004. Sea bed morphology of the Faroe-Shetland Channel derived from 3D seismic data sets. In Davies, R.J., J.A. Cartwright, S.A. Stewart, M. Lappin and R.J. Underhill, eds. 3D sesismic technology: application to the exploration of sedimentary basins. London, Geological Society, 53-61. (Geological Society Memoir 29.)

Lyngren, T.H., M.N. Berg and K. Berg. 1997. Subglacial features interpreted from 3D-Seismic. In Davies, T.A. and 7 others, eds. Glaciated continental margins: an atlas of acoustic images. London, Chapman \& Hall, 60-61.

Mosola, A.B. and J.B. Anderson. 2006. Expansion and rapid retreat of the West Antarctic Ice Sheet in eastern Ross Sea: possible consequence of over-extended ice streams? Quat. Sci. Rev., 25(17-18), 2177-2196.

Nyland, B., L.N. Jensen, J. Skargen, O. Skarpnes and T. Vorren. 1992. Tertiary uplift and erosion in the Barents Sea: magnitude, timing and consequences. In Larsen, R.M., H. Brekke, B.T. Larsen and E. Talleraas, eds. Structural and tectonic modelling and its applications to petroleum geology. Amsterdam, Elsevier, 153-162.

Ó Cofaigh, C., C.J. Pudsey, J.A. Dowdeswell and P. Morris. 2002. Evolution of subglacial bedforms along a paleo-ice stream, Antarctic Peninsula continental shelf. Geophys. Res. Lett., 29(8). (10.1029/2001GL014488.)

Ó Cofaigh, C., J.A. Dowdeswell, J. Evans and R.D. Larter. 2008. Geological constraints on Antarctic palaeo-ice-stream retreat. Earth Surf. Process. Landf., 33(4), 513-525.

Oppenheimer, M. 1998. Global warming and the stability of the West Antarctic ice sheet. Nature, 393(6683), 325-332.

Ottesen, D., J.A. Dowdeswell and L. Rise. 2005. Submarine landforms and the reconstruction of fast-flowing ice streams within a large Quaternary ice sheet: the 2500-km-long NorwegianSvalbard margin $\left(57^{\circ}-80^{\circ} \mathrm{N}\right)$. Geol. Soc. Am. Bull., 117(7), 1033-1050.

Praeg, D. 1997. Buried tunnel-valleys: 3D-Seismic morphostratigraphy. In Davies, T.A. and 7 others, eds. Glaciated continental margins: an atlas of acoustic images. London, Chapman \& Hall, 68-69.
Praeg, D. and D. Long. 1997. Buried sub- and proglacial channels: 3D-Seismic morphostratigraphy. In Davies, T.A. and 7 others, eds. Glaciated continental margins: an atlas of acoustic images. London, Chapman \& Hall, 66-67.

Rafaelsen, B., K. Andreassen, L.W. Kuilman, E. Lebesbye, K. Hogstad and M. Mitbø. 2002. Geomorphology of buried glacigenic horizons in the Barents Sea from three-dimensional seismic data. In Dowdeswell, J.A. and C. Ó Cofaigh, eds. Glacier-influenced sedimentation on high-latitude continental margins. London, Geological Society, 259-276. (Special Publication 203.)

Rignot, E. and S.S. Jacobs. 2002. Rapid bottom melting widespread near Antarctic ice sheet grounding lines. Science, 296(5575), 2020-2023.

Ryseth, A. and 7 others. 2003. Cenozoic stratigraphy and evolution of the Sørvestsnaget Basin, southwestern Barents Sea. Nor. J. Geol., 83(2), 107-130.

Sættem, J. 1994. Glacitectonic structures along the southern Barents shelf margin. In Croot, D.G. and W.P. Warren, eds. Formation and deformation of glacial deposits. Rotterdam, Balkema.

Sættem, J., L. Rise and D.A. Westgaard. 1992a. Composition and properties of glacigenic sediments in the Southwestern Barents Sea. Mar. Geotech., 10(3), 229-255.

Sættem, J., D.A.R. Poole, L. Ellingsen and H.P. Sejrup. 1992b. Glacial geology of outer Bjørnøyrenna, southwestern Barents Sea. Mar. Geol., 103(1/3), 15-51.

Sættem, J., L. Rise, K. Rokoengen and T. By. 1996. Soil investigation, offshore mid Norway: a case study of glacial influence on geotechnical properties. Global Planet. Change, 12(1-4), 271-285

Stokes, C.R., O.B. Lian, S. Tulaczyk and C.D. Clark. 2008. Superposition of ribbed moraines on a palaeo-ice-stream bed: implications for ice stream dynamics and shutdown. Earth Surf. Process. Landf., 33(4), 593-609.

Taylor, J., J.A. Dowdeswell, N.H. Kenyon and C. Ó Cofaigh. 2002. Late Quaternary architecture of trough mouth fans: debris flows and suspended sediments on the Norwegian Sea margin. In Dowdeswell, J.A. and C. Ó Cofaigh, eds. Glacier-influenced sedimentation on high-latitude continental margins. London, Geological Society, 55-71. (Special Publication 203.)

Vorren, T.O. and J.S. Laberg. 1997. Trough mouth fans - palaeoclimate and ice-sheet monitors. Quat. Sci. Rev., 16(8), 865-881.

Vorren, T.O., E. Lebesbye and K.B. Larsen. 1990. Geometry and genesis of the glacigenic sediments in the southern Barents Sea. In Dowdeswell, J.A. and J.D. Scourse, eds. Glaciomarine environments: processes and sediments. London, Geological Society, 269-288. (Special Publication 53.) 